\title{
ジオグリッド補強土壁の解析と設計
}

\section{ANALYSIS AND DESIGN FOR GEOGRID REINFORCED-SOIL WALL}

\author{
荻迫栄治*・落合英 俊** \\ By Eiji OGISAKO and Hidetoshi OCHIAI
}

\begin{abstract}
Most of the design methods for the geogrid reinforced-soil wall are based on the theory of rigid-plasticity which takes no account of displacement and deformation of reinforcing material in soil. However, pull-out resistance of the geogrid in soil depends on the displacement of the grid junction.

In this paper, finite element analyses of the geogrid reinforced-soil walls are performed. The method used here is capable of taking account of the mechanism of pull-out resistance of the geogrid in soil obtained from the pull-out tests on the geogrids. A practical design method for the geogrid reinforced-soil wall is proposed, which consists of a set of design charts determined from the finite element analyses.

Keywords : geogrid, reinforced-soil wall, design method, pull-out resistance
\end{abstract}

\section{1. まえがき}

近年，ジオグリッドを用いた補強土工法が注目されて いる.この工法はジオグリッドとよばれる補強材を盛土 や地盤中に敷設することによって盛土の安定性を高めた り, 基礎地盤の支持力や変形を改善しようとするもので あり, 盛土や地盤を改良・強化する重要な工法の 1 つに なっている.

ジオグリッド補強土壁工法は, 図一1に示すように裏 込め盛土中にジオグリッドを水平に配置し, 盛土全体の 安定性を高め, 壁面を垂直に保持しようとするものであ り，補強された裏込め盛土とそれを保護する壁面とが一 体となってはじめて安定した構造物となる点が特徴であ る. その点で従来の擁壁や土留め壁がその構造自体に よって裏込めの土圧をすべて支えようとしているのとは 根本的に異なっており, その設計に際しては従来と異 なった配慮が必要である.

これまでに提案されているジオグリッド補強土壁の設 計法の多くは, 土中の補強材の変位や変形を無視した剛

* 正会員 清水建設 (株) 土木本部設計部 (テ108 港区三田 3-13-16 三田 43 森ビル)

** 正会員 工博 九州大学教授 工学部水工土木学科 ( ₹812 福岡市東区箱崎 6-10-1)
塑性論に基づいている1). しかしながら，ジオグリッド 補強土壁は, 土の変形に伴って補強材が変形し, その変 形によって発生する補強材の張力や土と補強材間のせん 断抵抗によって補強効果が発揮されるものであり, その 際の土中のジオグリッドの引抜きせん断抵抗は，ジオグ リッドの節点の変位に依存している ${ }^{2) \sim 4)}$.

本論文においては，ジオグリッドの引抜き試験で明ら かにされた土中におけるジオグリッドの引抜き抵抗特性 を考慮し得る解析手法 ${ }^{4)-6)}$ を用いて, ジオグリッド補強 土壁の土圧特性, 壁面の変形特性および地盤の支持力 . 変形特性に関する解析を行い, その補強土効果について

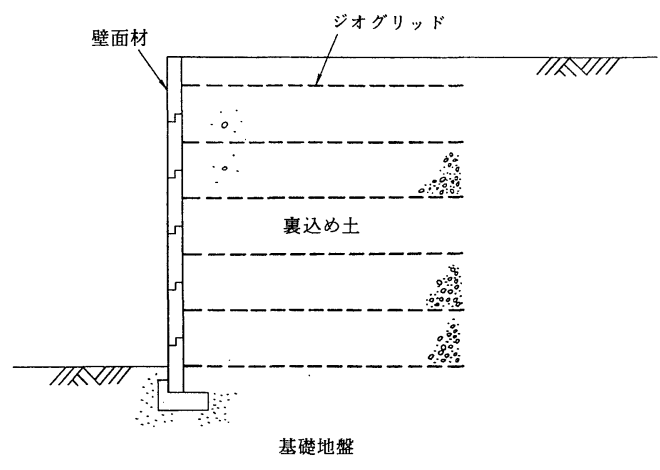

図一1ジオグリッド補強土壁の構成 
検討し，解析結果を利用した補強土壁の実用的な設計法 を提案したものである.

\section{2. ジオグリッド補強土壁の設計法の現状と問 題点}

ジオグリッド補強土壁は補強材であるジオグリッドの 高い引張り抵抗と, 盛土とジオグリッドとの摩擦抵抗に よって,盛土全体の安定を保持するものである.したがっ て, 壁面を構成する壁面材も通常厚さ $20 \mathrm{~cm}$ 程度のコ ンクリートパネル等が用いられる.このことは，鉄筋コ ンクリート擁壁等と比べると，基礎の不同沈下に対して はるかに追随性に富んでおり，特別に強固な基礎を必要 としないという補強土壁にとっての優れた利点の 1 つに なっている.

このように, ジオグリッド補強土壁は, 従来の鉄筋コ ンクリート擁壁や石積み, ブロック積みの土留め壁等の 抗土圧構造物とは機構や構造が異なっており，その設計 に際してもそれらの点を考慮することが必要である.

これまでに提案されているジオグリッド補強土壁の設 計法の多くは, 補強土壁を剛体とみなして, 滑動, 転倒 および支持力破壊に対する安定性の検討を行う外的安定 の検討と，局所的・部分的な力のつり合いを考慮し，補 強材の破断や引抜けに対する安定性の検討を行う内的安 定の検討を照查するものである．これらの設計法は，極 限つり合い法による静力学的検討に基ついており, 全体 の力のつり合い条件や境界での応力と荷重の条件は考慮 されているが, 土の内部, 補強材の内部および土と補強 材間でのひずみと変位の適合条件や境界でのひずみと変 位の条件については全く考慮されていない。すなわち， 土の自重や上載圧によって生じる壁面や基礎地盤の変 位・変形については何ら考虑していない.

従来のジオグリッド補強土壁の設計法が極限つり合い 法に基づいているのは，鉄筋コンクリート擁壁や土留め
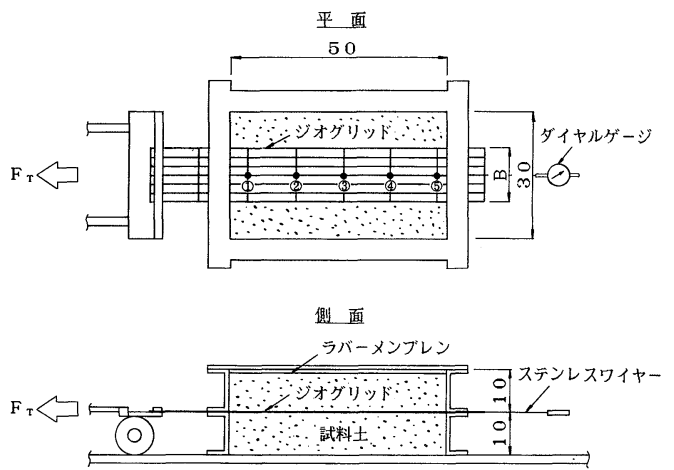

(単位: $\mathrm{cm}$ )
壁といった従来の抗土圧擁壁の設計法に準拠する形で考 案されたためと考えられる. しかしながら，従来の抗土 圧擁壁がそもそも変形を許さないような構造であるのに 対し, ジオグリッド補強土壁は補強材が変形することに よって補強効果が発揮されるものであり，その設計法も 従来の極限つり合い法にとらわれる必要はなく, ジオグ リッド補強土壁の機構や構造を考虑した合理的な設計法 を確立することが必要である.

本論文では, 上記の点にかんがみ, ジオグリッド補強 土壁の機構と特性を考慮した合理的な有限要素法解析を 行い，その結果を利用した実用的な設計法の提案を行っ たものである。

\section{3. ジオグリッド補強土壁の解析}

\section{（1）土中におけるジオグリッドの引抜き抵抗特 性2) 4)}

土中のジオグリッドが引張力を受けると, ジオグリッ ドは，各節点間で伸びを生じながら引き抜かれる，その ため, ジオグリッドの節点に生じる引抜き抵抗力は節点 の位置によって異なり，その分布は引抜き変位の進行に よって変化する. 図一2 に示す引抜き試験装置を用いた 実験結果 ${ }^{2}$ によると，土中のジオグリッドに生じる引抜 き抵抗力は凸形の分布をなし，最大抵抗力を示す節点位 置は変位の進行に伴って徐々に後方へ移動していくこと が明らかにされている．図一3は，このような実験結果 の一例であり，ジオグリッドの節点変位とそのときの節 点に作用する引抜き抵抗の関係を示したものである. 各 引抜き力 $F_{T}$ におけるジオグリッドの節点変位と引抜き せん断応力の曲線は，破線で描いた上下 2 本の限界曲線 の間に分布し，初期の変位段階ではグリッド節点に生じ る抵抗力は上限界曲線に沿って立ち上がるが, 変位の進 行に伴い, 前方の節点の抵抗力は低下し下限界曲線に漸 近する一方, 後続節点の抵抗力が上限界曲線に近づく傾

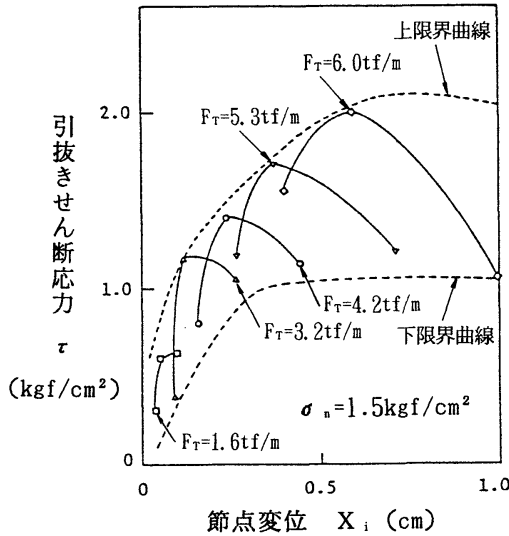

図-3 引抜きせん断応力の分布（砂，SR-2 の場合） 
向を示す.

これら上・下限界曲線は, 鉛直応力の大きさによって 異なる. 両限界曲線とも任意の変位レベルにおいて, 引 抜きせん断応力と鉛直応力との間には直線的関係があ り, 一種の摩擦則 $\left(\tau=c+f \cdot \sigma_{n}\right)$ が成立する ${ }^{2)}$. これ ら粘着力成分 $c$ および摩擦成分 $f$ と節点変位の関係は 図一4に示すとおりであり，土中のジオグリッドの各節 点における引抜きせん断応力の $c, f$ 成分は上下 2 本の 限界曲線で規定される範囲内にある.

（2） ジオグリッド補強土壁のモデル化 ${ }^{7) ~ 10) ~}$

土質地盤の応力・変形解析においては, 一般に地盤は 連続体として取り扱われる. しかし，ジオグリッド補強 土壁のように，土の中にジオグリッドのような異質な材 料を含む場合, 土とジオグリッドとの間ですべりや剝離 といった現象が生じる可能性があり，これらの不連続性 を評価し得る解析手法を用いることが必要である.

本論文においては, 土とジオグリッドの間の不連続性 を表現する方法としてジョイント要素を採用し，土とジ オグリッドとの間の鉛直方向の力の伝達およびせん断方 向の特異な摩擦特性やすべりを有する不連続面の挙動を 表現した. また，ジオグリッド自身は軸方向の引張り力 に対しては大きな抵抗力を有するが，曲げやねじりの抵 抗力は小さいことから, 軸方向の剛性のみを有する平面 トラス要素としてモデル化した.

そして，土中のジオグリッドの引抜きせん断抵抗がジ オグリッド節点の変位に依存して非線形的に変化するこ とを考慮するために，ジョイント要素のせん断剛性 $k_{s}$ にせん断変位依存性を導入する方法 ${ }^{4) \sim 6)}$ を用いた。図一 3 および図一4に示したように，摩擦成分 $f$ および粘着 力成分 $c$ は変位 $u$ 亡の関係において 2 本の上.下限界

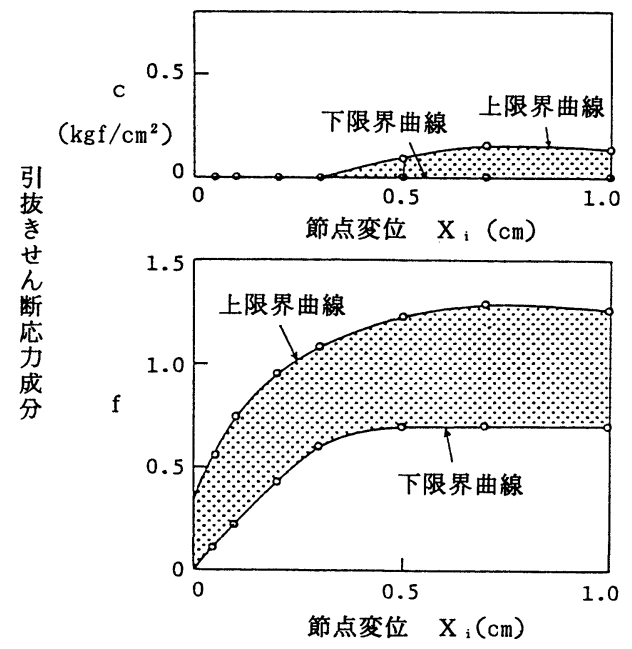

図一4 引抜きせん断応力の摩擦成分と粘着力成分の分布 (砂, SR-2 の場合)
曲線の間に分布し，この 2 本の曲線の間を規則性をもっ て変化する. したがって，この規則性を定式化すること によって, ジョイント要素のせん断方向の応力ーひずみ 関係を評価することができる，そこで，引抜きせん断応 力の摩擦成分 $f$ および粘着力成分 $c$ と変位 $u$ の関係を 図一5の模式図に示すように規定する．すなわち，変位 の小さい段階では, 上限界曲線上の点を通る直線とし, ある変位以降においては，上に凸の実験曲線を上限界曲 線上の点で折れる 2 本の直線で仮定するものとする. そ して $f$ および $c$ の下限界曲線の収束值をそれぞれ $f_{r}$, $c_{r}$ とすると, 最大変位を生じる先頭の節点の $f$ および $c$ の值は変位の進行につれて下限界曲線に近づくことか ら, $f$ および $c$ の值が $f_{r}$ および $c_{r}$ の值を越える領域 については, 最大変位 $u_{\max }$ を生じるジョイント要素の せん断応力成分 $f, c$ は収束值 $f_{r}, c_{r}$ の值をとるもの之 する。 そうすると, $f$ および $c$ と $u$ の関係は次のよう に規定される. 以下 $f \sim u$ の関係を例にとって説明する.

（I） まず， $f$ の值が $f_{r}$ を越えない領域（すなわち， $f=f_{r}$ の直線と上限界曲線との交点における変位を $u_{1}$ とすると, 最大変位 $u_{\max } \leqq u_{1}$ の領域）については, 原 点と上限界曲線上の $u_{\max }$ に対応する点とを結ぶ直線と する.

（II） $f$ の值が $f_{r}$ を越える領域（すなわち $u_{\max }>u_{1}$ の領域）については，原点および収束值 $\left(u_{\max }, f_{r}\right)$ と 上限界曲線上の点を結ぶ 2 本の直線で表わされるものと し，この 2 本の直線の傾きの絶対值は等しいとする．た だし，原点と上限界曲線上の点を結ぶ直線が下限界曲線 に接するまでとする.

（III）原点と上限界曲線上の点を結ぶ直線が下限界曲 線と接して以降は（II）と同様に 2 本の直線で与えられ るが， $u_{\max }$ がそれ以上大きくなっても，原点と上限界 曲線上の点を結ぶ直線は下限界曲線の接線と同一とす る.

このように規定すると，領域（Ｉ），（II），（III）にお

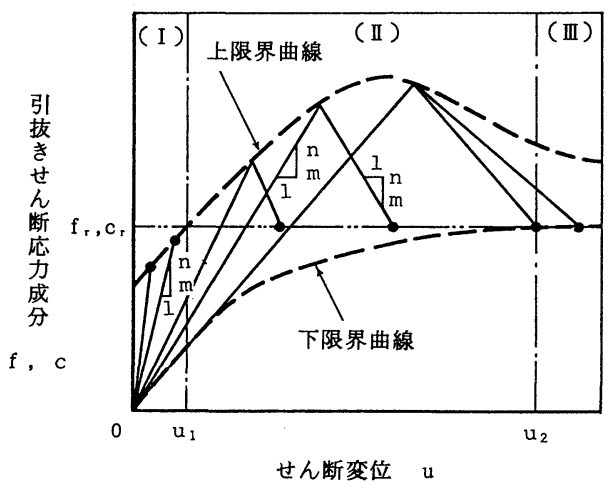

図一5 ジョイント要素のせん断剛性 $\boldsymbol{k}_{s}$ の決定法 
ける直線は最大せん断変位 $u_{\max }$ が決まれば一義的に定 まることになり，せん断応力の摩擦成分 $f$ はせん断変 位 $u$ の一次関数として, $f=m u$ で与えられることにな る. 同様の手順により, せん断応力の粘着力成分 $c$ に ついても, せん断変位 $u$ の一次関数として $c=n u$ で表 わされる.

したがって, せん断応力は,

$2 \tau=c+f \cdot \sigma_{n}=\left(n+m \cdot \sigma_{n}\right) u$

となり, ジョイント要素のせん断剛性率 $k_{s}$ は次式で与 えられる。

$2 k_{s}=n+m \sigma_{n} \cdot$

この方法によれば，引抜き試験の結果から得られる $f$ および $c$ の上・下限界曲線を用いれば, 最大せん断 変位 $u_{\max }$ の值によって係数 $m, n$ の值が規定され, し たがって式（2）によってジョイント要素のせん断剛性 率 $k_{s}$ が求められることになり, 引抜き試験から得られ る土とジオグリッドの引抜きせん断抵抗特性をジョイン 卜要素の応力-ひずみ関係の中に反映させることができ る(1) $^{4)}$.

また，平面トラス要素の軸剛性にはジオグリッドの引 張り強伸度特性を取り入れた. 壁面材としては通常壁体 全高さが縦板状のプレキャストコンクリートか, または, 複数のコンクリートパネルを金具等で緊結して用いる場 合が多い。そこで, 壁面材は曲げ剛性を有するはり要素 としてモデル化した. また, 不連続面を生じる土と壁面 材との境界面にもジョイント要素を設けた. 図一6にジ
オグリッド補強土壁の有限要素モデルを示す.

\section{（3）解析条件および解析手順}

図一7は, 解析ケースを示したものである. 図中, $H$ が壁高， $h$ が補強材の敷設間隔， $L$ が敷設長である. 補 強土壁においては, 補強材を敷設することにより壁面に 作用する土生や壁面変位が低減し, これらの補強土効果 は設計の際に決定しなければならない補強材の敷設長や 敷設間隔亡密接に関係している。そこで，それらの関係 を検討するために，敷設間隔 $h$ を $h / H=1.0,0.5,0.2$ および 0.1 の 4 種類に, また，敷設長 $L$ を $L / H=0.2$, $0.4,0.6$ および 0.8 の 4 種類にそれぞれ変えて解析を 行った。 また，通常補強材は金具等によって壁面材と連 結されることから，ジオグリッドの端部は各ケースとも 壁に固定されているものとした．また，補強土効果は補 強土壁構造体の変位・変形と密接に関係しており, その 変位・変形は補強土壁ならびにそれを支える基礎地盤に 影響を受ける. そこで, 解析領域としては補強土壁構造 体のみならず基礎地盤も含めるものとした．図一8に解 析モデルの一例 $(h / H=0.1, L / H=0.8$ のケース) を 示す。図中の $D$ は基礎地盤厚さである。

解析に用いた土およびジオグリッドは砂および一軸延 伸グリッド SR-2 で，土とジオグリッドの相互の関係に は, ジオグリッドの引抜き試験から得られた前述の図一 4 の結果を採用した. また，解析に際しては，土を Duncan-Chang ${ }^{11)}$ の提案による非線形弾性体と仮定し, 次の接線弾性係数を用いた.
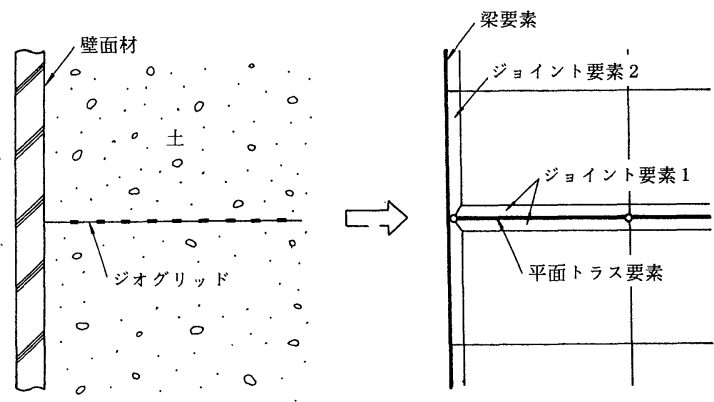

図一～ジオグリッド補強土壁のモデル化

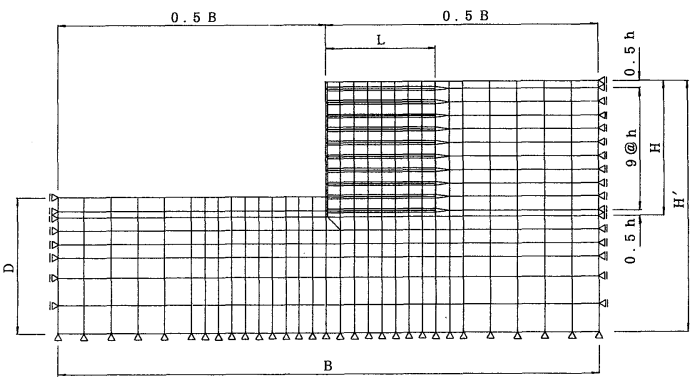

図—8 解析モデル $(h / H=0.1, L / H=0.8$ のケース $)$

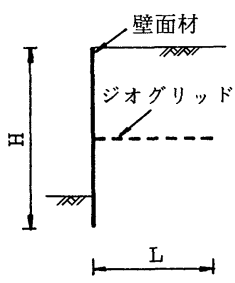

(a) Model-1

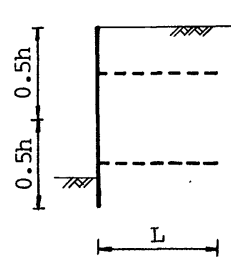

(b) Mode1-2

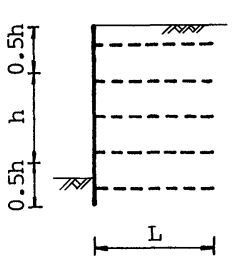

(c) Model-3

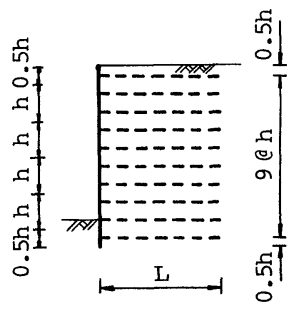

(d) Model-4

図一7 解析ケース 
表一1 土質パラメーター

\begin{tabular}{|c|c|c|c|c|c|c|c|}
\hline & \multirow{2}{*}{$\begin{array}{c}\text { 単位体種重量 } \\
\gamma\left(\mathrm{t} / \mathrm{m}^{3}\right)\end{array}$} & \multirow{2}{*}{$\begin{array}{l}\text { 粘着力 } \\
\mathrm{c}\left(\mathrm{tf} / \mathrm{m}^{2}\right)\end{array}$} & \multirow{2}{*}{$\begin{array}{c}\text { 内部魔摖角 } \\
\phi\left(^{\circ}\right)\end{array}$} & \multicolumn{3}{|c|}{ 実験定数 } & \multirow{2}{*}{$\begin{array}{c}\text { ポアソン比 } \\
v\end{array}$} \\
\hline & & & & K & $\mathrm{n}$ & $R_{f}$ & \\
\hline & 1.8 & 0 & 38 & & 1.0 & 0.9 & \\
\hline & & & 5 & & & & \\
\hline
\end{tabular}

表一2ジオグリッドおよび壁面材の物性值

\begin{tabular}{|c|c|c|c|}
\hline & $\begin{array}{c}\text { 彈性係数 } \\
\mathrm{E}\left(\mathrm{tf} / \mathrm{m}^{2}\right)\end{array}$ & $\begin{array}{r}\text { 眯面積 } \\
\mathrm{A}\left(\mathrm{m}^{2}\right)\end{array}$ & $\begin{array}{c}\text { 断面 } 2 \text { 次モーメント } \\
\text { I }\left(\mathrm{m}^{4}\right)\end{array}$ \\
\hline ジオグリッド & $1.62 \times 10^{5} *$ & 0.0012 & - \\
\hline 壁面材 & $2.45 \times 10^{6}$ & 0.18 & $4.86 \times 10^{-4}$ \\
\hline
\end{tabular}

$$
E_{t}=\left\{1-\frac{R_{\digamma}(1-\sin \phi)\left(\sigma_{1}-\sigma_{3}\right)}{2 c \cos \phi+2 \sigma_{3} \sin \phi}\right\}^{2} \cdot K p_{a}\left(\frac{\sigma_{3}}{p_{a}}\right)^{n}
$$

ここに， $c, \phi$ は土の粘着力および内部摩擦角， $\sigma_{1}, \sigma_{3}$ は最大および最小主応力, $K, n, R_{f}$ は実験定数である. このモデルは, 実験的事実に基づき，土の応力-ひずみ 関係を双曲線で近似することによって土の非線形性を評 価したものであり，実用的で容易に非線形解析に適用で きるという利点から従来よりよく用いられている。しか し反面, 理論的根拠に欠ける点があったり, ダイレイタ ンシーの特性を評価できないといった不十分な点も有し ている.しかし, 本解析では, 主に土と補強材のイン夕 ラクションに重点を置いていることから，実用的なこの モデルを採用することとした. 土質定数の選定に際して は，裏込め土については三軸圧縮試験結果に基づいて決 定し，基礎地盤については比較的軟弱な地盤上でも施工 可能であるという補強土壁の特性を考慮し，基礎地盤を 裏込め土より軟弱なものと想定し，既往の文献 ${ }^{12)}$ にる 值を用いた．また，壁面材は厚さ $18 \mathrm{~cm}$ のンクリー 卜板とし, 裹込め盛土の自重による変形解析を行った. なお, 自重は盛土の盛り立て過程を考慮し, 漸増荷重亡 して解析した．表一1に解析に用いた土質パラメーター を，また，表一2にジオグリッドおよび壁面材の物性值 を示す。

\section{（4）解析結果および考察}

ジオグリッド補強土壁は補強材を敷設することで壁面 に作用する土圧や壁面変位を抑えることによって全体の 安定性を保持するものであり，したがって，作用土圧や 壁面変位の低減といった，いわゆる補強土効果が設計上 きわめて重要である．また，ジオグリッド補強土壁は沈 下や変形に対する追随性が大きいことから，この補強土 効果は, 補強土壁構造体の変位・変形ならびにそれを支 える基礎地盤の変形や支持力と密接に関係している. し たがって，ジオグリッド補強土壁の合理的な設計法を確 立するためには，前述した，壁面に作用する土圧や壁面 変位ならびに基礎地盤の変形・支持力といった補強土効 果に関係する項目を検討することが必要である．このよ うな観点から, 本論文では下記の項目について解析結果

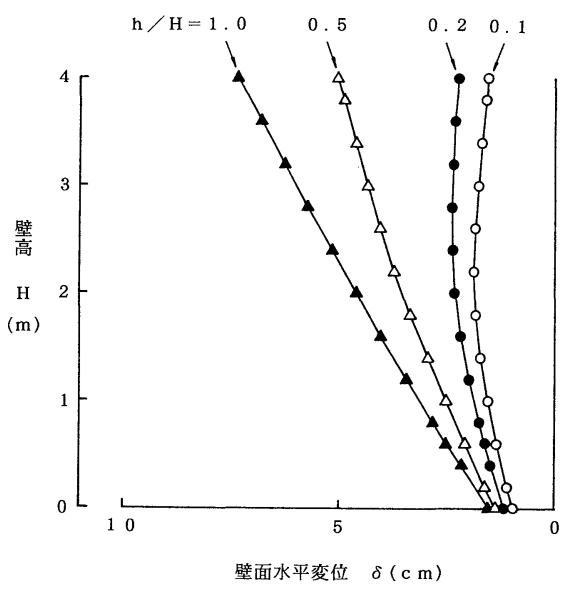

図一9 壁面変位の分布 $(H=4 \mathrm{~m}, L / H=0.6$ の場合 $)$

を分析することとする.

a) 壁面変位

図一9 は, $H=4 \mathrm{~m}$ および $L / H=0.6$ の場合の壁面の 水平変位の分布を示したものである. 壁面変位は補強材 の敷設間隔が小さくなるにつれて減少する. また，変形 形状に関しては，敷設間隔が $h / H=1.0$ の場合は壁の 下端から上端に向かってほぼ直線的に変位が増加するの に対して, $h / H=0.5$ の場合では，壁高の中間点付近を 境にして, それより上方の変位の増加が下方に比べて小 さくなり，ゆるやかな上弦曲線状となる，これは，上部 に敷設された補強材が効果的に作用して，上方の変位の 発生を抑制しているためと考えられる.この傾向は $h / H=0.2$ および 0.1 の場合にはさらに顕著で，壁高の 中間付近に変曲点が現われ，この変曲点で変位が最大と なり，それより上方にいくに従って，変位は徐々に減少 し，変形形状は弓状となる.

b）壁面に作用する土圧

図一10 は, $H=4 \mathrm{~m}, L / H=0.6$ の場合の壁面に作用 する土圧分布を示したものである。図中，実線が解析值 を，一点鎖線がクーロンの主働土圧を表わし，破線の位 置にジオグリッドが敷設されている.この図によれば, ジオグリッドを敷設することによって，その敷設位置の 土圧が減少し, また, 補強材の数が増加し敷設間隔が小 さくなるに従って, 土圧の減少量は大きくなる，また， 敷設間隔が大きい $h / H=1.0,0.5$ および 0.2 の場合は, 補強によって土圧が減少した部分とそうでない部分との 間に差があり，全体としてジグザグした土圧分布となる が, $h / H=0.1$ の場合は, 土圧の減少域と非減少域の差 がほとんどなくなり，なめらかな土圧分布となる。

ここで, 補強材による土圧の低減効果を定量的に評価 する指標として, 土圧低減率 $R_{P}$ を次式によって定義す る. 


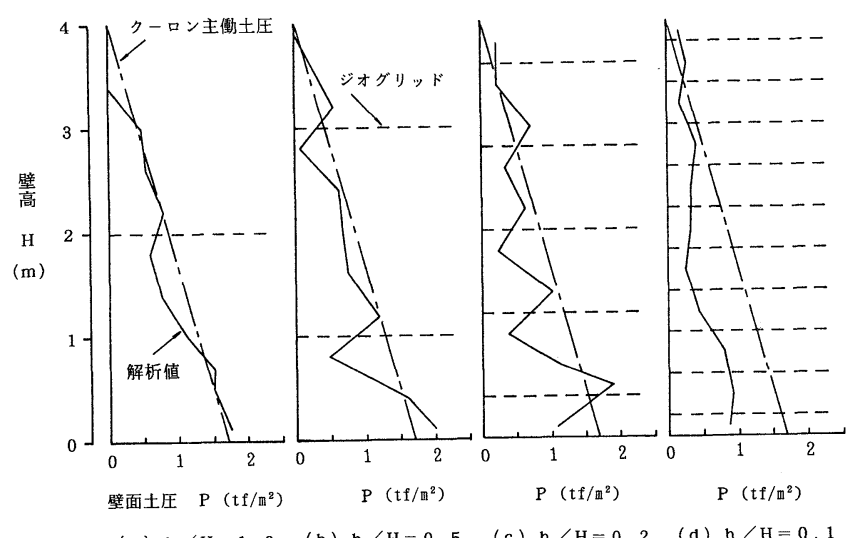

$\begin{array}{ll}\text { (a) } \mathrm{h} / \mathrm{H}=1.0 & \text { (b) } \mathrm{h} / \mathrm{H}=0.5\end{array}$

(c) $\mathrm{h} / \mathrm{H}=0.2$

(d) $\mathrm{h} / \mathrm{H}=0.1$

図一10 壁面に作用する土圧の分布 $(H=4 \mathrm{~m}, L / H=0.6$ の場合）

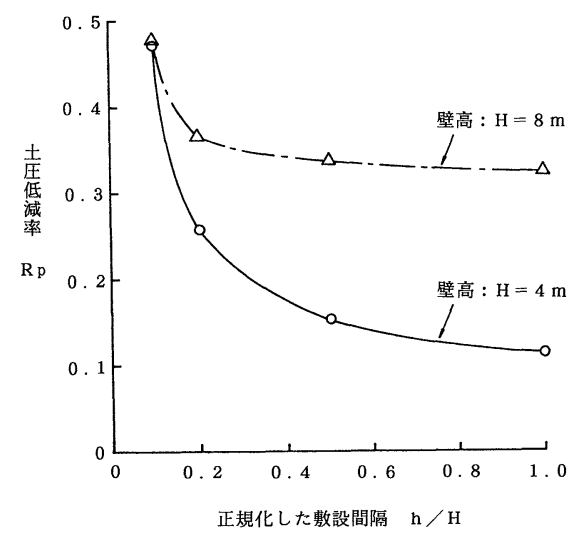

図一11 壁面に作用する土圧の低減率 $(L / H=0.6$ の場合)

$R_{P}=1-\left(P_{G} / P_{0}\right)$

ここに， $P_{0}$ は無補強時のクーロン主働土圧による壁面 合土圧， $P_{G}$ は補強時の解析値による壁面合土圧である.

図一11 は, 式 ( 4 )で定義した土圧低減率をジオグリッ ドの敷設間隔に対して整理した結果である。ここで，図 一11 の横軸はジオグリッドの敷設間隔 $h$ を壁高 $H$ で正 規化した值である。この図から, 補強材の敷設間隔が小 さくなるに従って土圧の低減率は増加し，しかも，その 増加の様子は双曲線状を示しており, 敷設間隔が小さく なるほど，土圧低減率は急激に増加する，また，壁高に よって低減率の值が異なるが, その差は補強材の敷設間 隔が小さくなるほど減少し， $h / H=0.1$ になると両者の 低減率はほとんど一致する。

一方, 図一12 は, $h / H=0.1$ の場合についてジオグ リッドの敷設長と補強材による土圧の低減率の関係を示 したものである．土圧の低減率は壁高によらずほぼ一致 した值を示す.また, 敷設長に関しては $L / H=0.6$ で ピークを示し，最適な敷設長が存在することを示してい

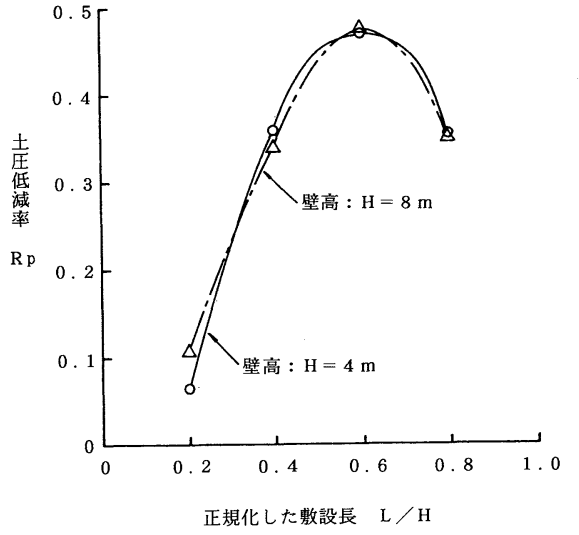

図一12 壁面に作用する土圧の低滅率 $(h / H=0.1$ の場合 $)$

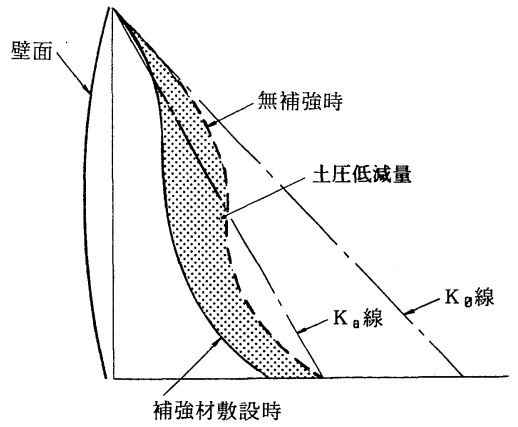

図一13＼cjkstart壁面の変形に対応する土圧分布の概念図

る.これは, 図一13に示すように壁面に作用する土圧 は壁面の変形状態によって恋化し, 壁上部の土は壁面変 位が小さいため, 下部の土に比べて静止土圧状態に近く なる。一方, 補強材に働く張力によって土圧は低減され, 最終的に壁面に作用する土圧は図の実線で示すような分 布になると推測される。このように解釈すると，土圧の 低減量は図の破線と実線の差の部分ということになり， 
この量は補強材の敷設長が長いほど大きいと予想され る.しかし，敷設長が長くなるにつれ，壁面変位の減少 に応じて，破線の土王分布は静止土王分布に近づいてい くため, 壁面に作用する最終的な土圧は両者の相対的な 関係によって決まるものと思われる。したがって，図一 12 において, $L / H=0.6$ から $L / H=0.8$ にかけて, 無 補強時のクーロンの主働土圧を基準にした土圧低減率が 減少しているのは, 敷設長増加 $(L / H=0.6 \rightarrow L / H=$ 0.8) による土圧低減量の増加分よりも, 壁面変位の減 少によって静止土圧へ近づくことによる土圧の増加分の 方が大きかったためと解釈できる。すすおち，補強材の 敷設長をある程度より長くすれば，補強材後端部がアン カ一的な働きをし変位を抑える一方で, 土王分布はより 静止土圧状態に近づいていくものと考えられ，したがっ て，作用土圧に関しては，その大きさが最小となるよう な補強材の敷設長が存在するといえる.

図一11および図一12の結果から，壁面に作用する土 圧はクーロンの主働土圧に対して最大で約 5 割程度減少 することがわかる.

c）裏込め土表面の沈下量

図-14 は, $H=4 \mathrm{~m}$ および $L / H=0.6$ の場合の裏込 め土表面の絶対沈下量の分布を示している. 補強材の敷 設間隔が小さくなるにつれて，沈下量は減少する．特に 敷設間隔 $h / H$ が大きいときは, 全体的に沈下が生じる のに対し， $h / H$ が 0.2 以下になると，ジオグリッドで

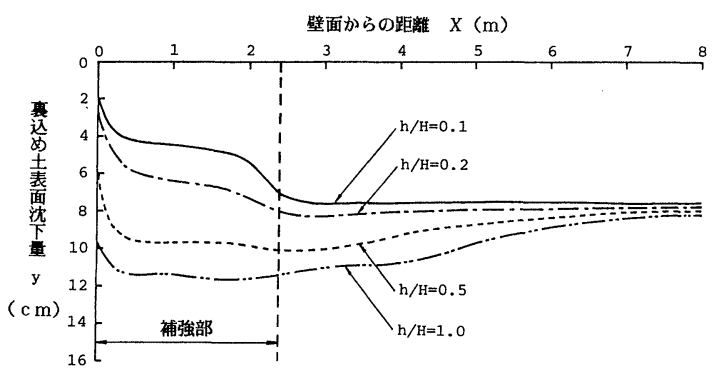

図一14 裏込め土表面沈下量の分布 ( $H=4 \mathrm{~m}, L / H=0.6$ の場合)

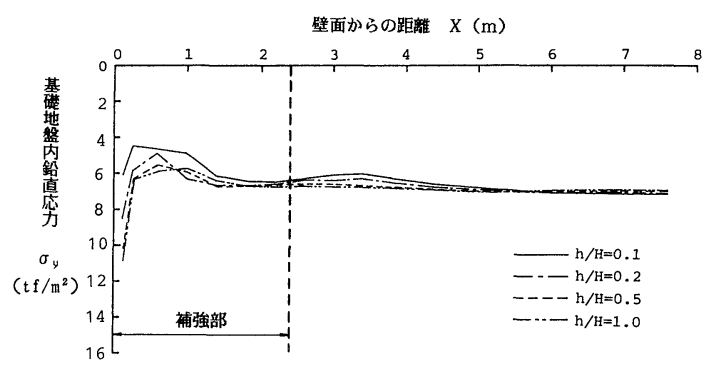

図一15 基礎地盤内に発生する鉛直応力の分布 $(H=4 \mathrm{~m}, L / H=0.6$ の場合)
補強された部分の沈下量が抑えられ, 補強部と無補強部 の間に沈下量の差が生じる.これは, 補強材の敷設間隔 が小さくなるにつれて, 補強領域の一体化が進むためで ある・

d）基礎地盤内の鉛直応力

図一15 は, $H=4 \mathrm{~m}$ および $L / H=0.6$ の場合の裏込 め土直下の基礎地盤内に発生する鉛直応力の分布を示し たものである．壁直下の地盤には大きな鉛直応力が発生 する、これは，壁下端まわりの転倒モ一ドが生じ，応力 集中が起きたためと考えられる，しかし，この鉛直応力 は補強材の敷設間隔が小さくなるに従ってしだいに減少 し，敷設間隔 $h / H$ が 0.1 になると土被り圧 $7.2 \mathrm{tf} / \mathrm{m}^{2}$ 以下となる.また，壁面から約 $1.5 \mathrm{~m}$ 以上離れると， 補強材の敷設間隔が違っても，鉛直応力にあまり差はみ られない。したがって, 補強材は壁直下の基礎地盤に発 生する応力集中を軽減するのに効果的であり，補強材を 敷設することにより支持力破壊に対する安定性を高める ことができる.

\section{4. ジオグリッド補強土壁の設計法の提案}

以上の有限要素法解析結果より, 補強土壁の変形量や 作用土圧等の低減効果は，ジオグリッドの敷設長や敷設 間隔によって異なることが明らかとなった。 そこで，そ れらの関係を定量的に表わしたジオグリッド補強土壁の 設計図表を作成した。これらの設計図表を用いて設計を 行う際の手順と方法は次のとおりである.

\section{(1) 設計手順}

設計は, 図一16に示す設計フローに従って, 次の手 順により行う.

a）設計条件の設定および設計図表の選択

補強土壁および基礎地盤の幾何形状，補強材の材料物 性, 盛土および基礎地盤の土質定数ならびに上載荷重等 の設計条件について設定し，その設計条件に対応する設 計図表の選択を行う。

b）補強材の必要敷設長および敷設間隔の選定

壁面の水平変位量，基礎地盤の沈下量および基礎地盤 の支持力に関する設計図表を用いて，与えられた壁面の 許容変位量 $\delta_{a}$, 基礎地盤の許容沈下量 $S_{a}$ および基礎地 盤の許容支持力 $q_{a}$ のそれぞれに対する必要敷設長およ び敷設間隔を読み取り， $\delta_{a}, S_{a}, q_{a}$ のすべてを満たす必 要敷設長と敷設間隔を選定する.

c） ジオグリッドの破断のチェック

ジオグリッドに発生する張力に対する設計図表を用い て，b）で選定した必要敷設長および敷設間隔に対して ジオグリッドの破断に対するチェックを行う．この際， 発生最大張力 $T_{\max }$ が設計引張強度 $T_{D}$ を越える場合, 改めて, $T_{\max } \leqq T_{D}$ となるような敷設長および敷設間隔 


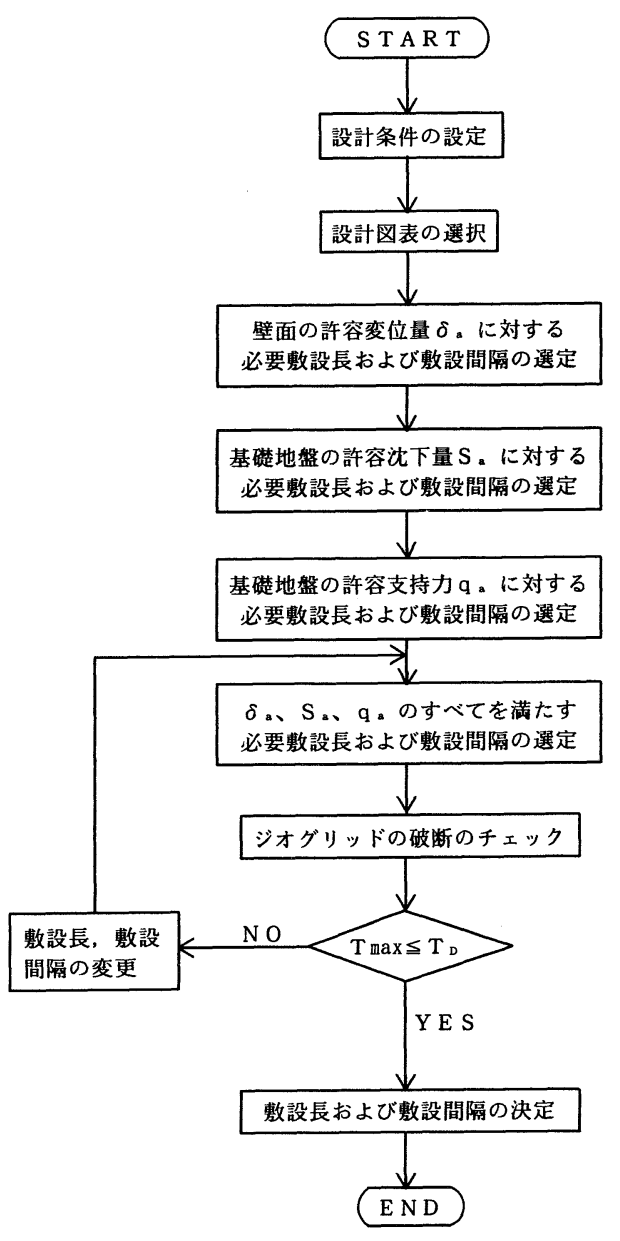

図一16 ジオグリッド補強土壁の設計フロー

を選定し直す.そして，この值が許容值 $\delta_{a}, S_{a}, q_{a}$ を 満たし得るかどうか再度確認し, 最終的な敷設長と敷設 間隔を決定する.

（2）設計方法および設計例

4. (1) に述べた手順による設計の方法について, 例 を用いて説明する.

a) 設計条件

設計例として以下の設計条件を設定する.

- 壁高：H=8 m

- 基礎地盤厚 : $D=8 \mathrm{~m}$

・壁の根入れ深さ： $D_{f}=1.2 \mathrm{~m}$

・補強材：一軸延伸グリッド SR-2

規格引張強度 $T_{Q}=8 \mathrm{tf} / \mathrm{m}$

設計引張強度 $T_{D}=\alpha T_{Q}$

$$
\begin{aligned}
& =0.4 \times 8 \\
& =3.2 \mathrm{tf} / \mathrm{m}
\end{aligned}
$$

- 盛土材：単位体積重量 $\quad \gamma=1.8 \mathrm{tf} / \mathrm{m}^{3}$ 内部摩擦角 $\phi=38^{\circ}$

$$
\text { 粘着力 } \quad c=0
$$

- 基礎地盤：単位体積重量 $\gamma=1.8 \mathrm{tf} / \mathrm{m}^{3}$

$$
\begin{array}{ll}
\text { 内部摩擦角 } & \phi=35^{\circ} \\
\text { 粘着力 } & c=0
\end{array}
$$

- 壁面材厚：18 cm

-上載荷重： $q=1 \mathrm{tf} / \mathrm{m}^{2}$

- 壁面の許容変位量 : $\delta_{a}=8 \mathrm{~cm}$

- 基礎地盤の許容沈下量： $S_{a}=10 \mathrm{~cm}$

- 基礎地盤の許容支持力 : $q_{a}=20 \mathrm{tf} / \mathrm{m}^{2}$

上記の条件に対して，設計図表として図一17～図一19 および図一21 が得られる.

b）壁面の許容変位量に対する必要敷設長と敷設間隔 の選定

図一17に示す設計図表を用いて，壁面の許容変位量 $\delta_{a}$ に対して必要なジオグリッドの敷設長および敷設間 隔を選定する。この図には，壁面の最大水平変位とジオ グリッドの敷設長および敷設間隔の関係が示されてい る. 設計図表の用い方は, まず, 既知の許容変位量 $\delta_{a}$ を横軸上に取り，正規化した敷設間隔 $h / H$ に到達する まで垂直に移動し, 到達後水平に移動して縦軸との交点 から必要な敷設長 $L / H$ を読み取る. 設計例では， $\delta_{a}=$ $8 \mathrm{~cm}$ に対して $, L / H=0.72, h / H=0.1$ となる.

c）基礎地盤の許容沈下量に対する必要敷設長および 敷設間隔の選定

図一18に示す設計図表を用いて，基礎地盤の許容沈 下量 $S_{a}$ に対して必要なジオグリッドの敷設長および敷

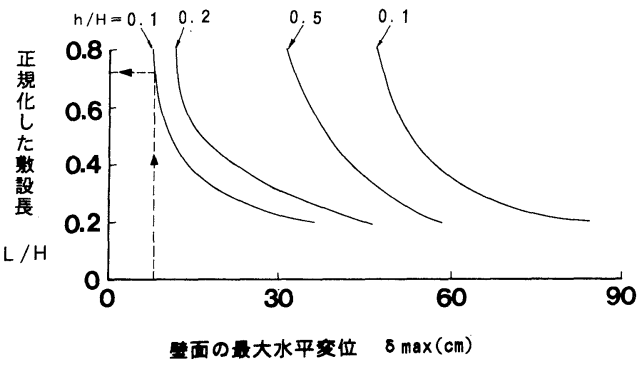

図一17 壁面変位量に関する設計図表

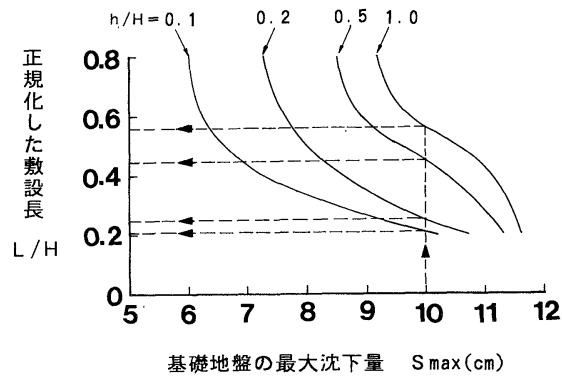

図一18＼cjkstart基礎地盤の沈下量に関する設計図表 

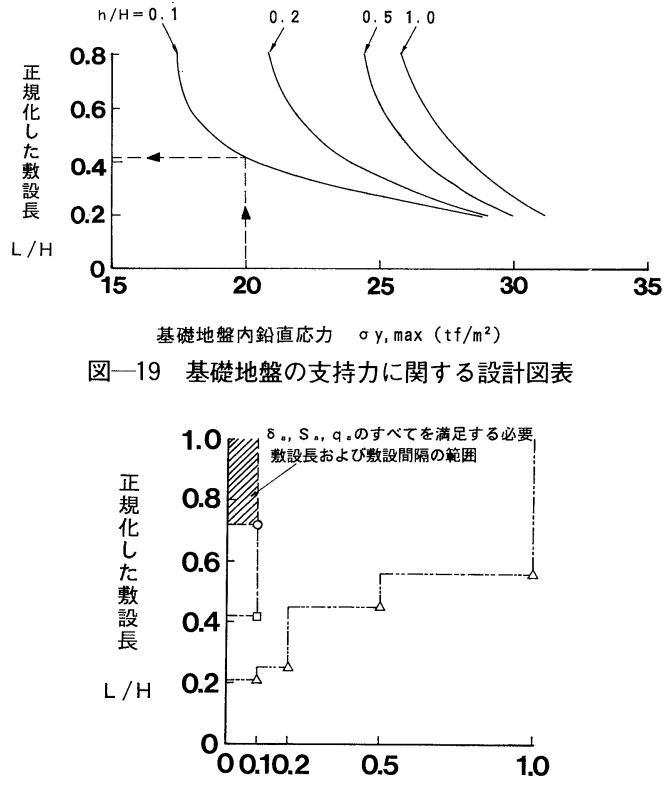

正規化した敷設間隔 $\mathrm{h} / \mathrm{H}$

図一20 必要敷設長および敷設間隔の選定

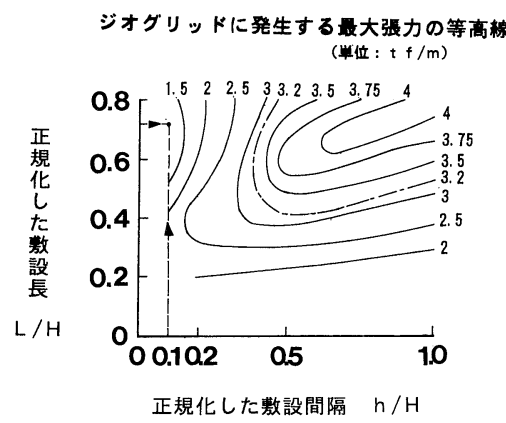

図一21 ジオグリッドの破断に関する設計図表

設間隔を選定する。この図には，基礎地盤の最大沈下量 とジオグリッドの敷設長および敷設間隔の関係が示され ている．設計図表の用い方は，上記 b) と同様である. 設計例では, $S_{a}=10 \mathrm{~cm}$ に対して,$L / H=0.21$ と $h / H$ $=0.1, L / H=0.25$ と $h / H=0.2, L / H=0.45$ と $h / H$ $=0.5$ および $L / H=0.56$ と $h / H=1.0$ の 4 通りの組合 せがある。

d）基礎地盤の許容支持力に対する必要敷設長と敷設 間隔の選定

図一19に示す設計図表を用いて，同様に基礎地盤の 許容支持力 $q_{a}$ に対して必要なジオグリッドの敷設長お よび敷設間隔を選定する。この図には，ジオグリッドが 敷設されている裏込め盛土部直下の基礎地盤内に発生す る最大鈶直応力とジオグリッドの敷設長および敷設間隔 の関係が示されている. 設計例では， $q_{a}=20 \mathrm{tf} / \mathrm{m}^{2}$ に対
して $L / H=0.42, h / H=0.1$ となる.

e ) $\delta_{a}, S_{a}, q_{a}$ のすべてを満足する必要敷設長および 敷設間隔の選定

上記 b)，c），d）のそれぞれで求まった $L / H$ と $h / H$ の組合せの中で, $\delta_{a}, S_{a}, q_{a}$ のすべての条件を満たすも のを選択する（一般に $L / H$ が大きく， $h / H$ が小さい ものである). 設計例では, 図一20に示すように, $L / H$ $=0.72, h / H=0.1$ である.

f）ジオグリッドの破断のチェック

図一21に示す設計図表を用いて，上記 e）で選定し た必要敷設長 $L / H$ と敷設間隔 $h / H$ に対してジオグ リッドの破断のチェックを行う.この図には, ジオグリッ ドに発生する最大張力とジオグリッドの敷設長および敷 設間隔の関係が等張力線の形で示されている. 設計例で は, $L / H=0.72, h / H=0.1$ に対応する点は, 図上で $T_{\max }<1.5 \mathrm{tf} / \mathrm{m}$ の位置にあり, 設計引張強度 $T_{D}=3.2$ $\mathrm{tf} / \mathrm{m}$ より小さいので安全である.

もし，ここで， $T_{\max }>T_{D}$ である場合，図上で $T_{\max } \leqq$ $T_{D}$ となるような $L / H$ および $h / H$ を選定し直して, 再 度, e) 以後のチェックを行う必要がある。

g) ジオグリッドの敷設長および敷設間隔の決定

上記 b)～f） の手順を経て最終的に求まる敷設長と敷 設間隔を決定する．設計例では， $L / H=0.72, h / H=$ 0.1 であるから，最終的に決まる敷設長および敷設間隔 は $L=0.72 H=0.72 \times 8=5.8 \mathrm{~m}, h=0.1 H=0.1 \times 8=$ $0.8 \mathrm{~m}$ となる。

\section{5. ま と め}

従来提案されているジオグリッド補強土壁の設計法の 多くは, 土中の補強材の変位や変形を無視した剛塑性論 に基づいている．しかしながら，ジオグリッド補強土壁 は, 本来, 補強材であるジオグリッドが変形することに よって補強効果が発揮されるものであり，その際に発生 する土とジオグリッド間の引抜きせん断抵抗は，ジオグ リッド節点の変位に依存している.

本論文では，ジオグリッド補強土壁の機構や構造を考 慮した合理的な設計法を確立することを目的として，ジ オグリッドの引抜き試験で明らかにされた土中における ジオグリッドの引抜きせん断抵抗特性を考慮した解析手 法を用いて，ジオグリッド補強土壁の有限要素法解析を 実施した。解析結果より，変形量や作用土圧等の低減効 果はジオグリッドの敷設長や敷設間隔によって異なるこ とを明らかにし，それらの関係を定量的に表わした設計 図表を作成することによって, 新しい設計法を提案した。 この設計法によれば, 簡単な手順に従って迅速にジオグ リッド補強土壁の変形の検討に基づいた合理的な設計を 行うことができる. 
なお, 本研究は文部省科学研究費 (一般研究 $(B)$ 01460179, 研究代表者: 九州大学工学部教授 落合英俊) の援助を受けた.

また, 本研究にあたり, 九州大学工学部林 重徳助 教授, 佐賀大学理工学部 坂井 晃助教授には, 日頃よ りご指導，ご協力をいただいている.ここに，深く謝意 を表します。

\section{参 考 文 献}

1) Jones, C. J.F.P. : Design and Construction Methods, Symp. Polymer Grid Reinforcement in Civil Engineering, Paper No.6.1, 1984.

2）林 重徳・山内豊聡・落合英俊・孫 純鐘：土中におけ るポリマーグリッドの引抜き抵抗機構, 土と基礎, Vol. 33, No. 5, pp. 21〜26, 1985.

3) Ochiai, H. et al. : Field Pull-Out Test of Polymer Grid in Embankment, Proc. Int. Geotechnical Symp. on Theory and Practice of Earth Reinforcement, pp. 147 $151,1988$.

4) Ochiai, H. et al. : Pull-Out Behavior of Polymer Grid in Soils and Its Analytical Method, Memoirs of the Fuculty of Eng., Kyushu Univ., Vol.48, No.2, pp. 125 139, 1988.

5）坂井 晃・落合英俊・林 重徳：ジオグリッドを用いた 補強土の変形解析法, 土質工学会論文報告集, Vol.27,
No. 3, pp. 147 155, 1987.

6) Ochiai, H. and Sakai, A. : Analytical Method for Geogrid-Reinforced Soil Structures, Proc. 8th Asian Regional Conf. on SMFE, pp. 483 486, 1987.

7）荻迫栄治・落合英俊・林 重徳・坂井 晃：ポリマーグ リッド補強土擁壁の土圧と変形, 第 2 回ジオテキスタイ ルシンポジウム論文集, pp. 29 34, 1987.

8) Ochiai, H., Hayashi, S., Ogisako, E. and Sakai, A. : Analysis of Polymer Grid-Reinforced Soil Retaining Wall, Proc. 6th Int. Conf. on Numerical Methods in Geomechanics, Vol.2, pp.1449 1454, 1988.

9) Ogisako, E., Ochiai, H., Hayashi, S. and Sakai, A. : FEM Analysis of Polymer Grid Reinforced-Soil Retaining Walls and Its Application to the Design Method, Proc. Int. Geotechnical Symp. on Theory and Practice of Earth Reinforcement, pp. 559 564, 1988.

10）荻迫栄治・落合英俊・林 重徳：ジオグリッドを用いた 補強土壁の設計図表, 第 3 回ジオテキスタイルシンポジ ウム論文集, pp. 8 14, 1988.

11) Duncan, J.M. and Chang, C. V. : Nonlinear Analysis of Stress and Strain in Soils, Journal of Soil Mech. and Found. Div., ASCE, SM5, pp. 1629 1653, 1970.

12) Mitchell, J. K. and Gardner, W. S. : Analysis of LoadBearing Fills over Soft Subsoils, Journal of Soil Mech. and Found. Div., ASCE, SM11, pp. 1549 1571, 1971.

(1990.1.11 • 受付) 